\title{
Staphylococcus aureus enterotoxins induce IL-8 secretion by human nasal epithelial cells
}

\author{
Garrett J O'Brien, Gareth Riddell, J Stuart Elborn, Madeleine Ennis and \\ Grzegorz Skibinski*
}

\author{
Address: Respiratory Research Group, School of Medicine and Dentistry, Queen's University Belfast, Grosvenor Road, Belfast BT12 6BJ, Northern \\ Ireland, UK \\ Email: Garrett J O'Brien - obriengarrett@yahoo.ie; Gareth Riddell - garethriddell@yahoo.com; J Stuart Elborn - Stuart.Elborn@bch.n-i.nhs.uk; \\ Madeleine Ennis - m.ennis@qub.ac.uk; Grzegorz Skibinski* - g.skibinski@qub.ac.uk \\ * Corresponding author
}

Published: 04 September 2006

Respiratory Research 2006, 7:115 doi:10.1186/1465-9921-7-115

This article is available from: http://respiratory-research.com/content/7/I/II5

(C) 2006 O'Brien et al; licensee BioMed Central Ltd.

This is an Open Access article distributed under the terms of the Creative Commons Attribution License (http://creativecommons.org/licenses/by/2.0), which permits unrestricted use, distribution, and reproduction in any medium, provided the original work is properly cited.
Received: 21 December 2005

Accepted: 04 September 2006

\begin{abstract}
Background: Staphylococcus aureus produces a set of proteins which act both as superantigens and toxins. Although their mode of action as superantigens is well understood, little is known about their effects on airway epithelial cells.

Methods: To investigate this problem, primary nasal epithelial cells derived from normal and asthmatic subjects were stimulated with staphylococcal enterotoxin A and B (SEA and SEB) and secreted (supernatants) and cell-associated (cell lysates) IL-8, TNF- $\alpha$, RANTES and eotaxin were determined by specific ELISAs.

Results: Non-toxic concentrations of SEA and SEB $(0.01 \mu \mathrm{g} / \mathrm{ml}$ and $1.0 \mu \mathrm{g} / \mathrm{ml})$ induced IL-8 secretion after $24 \mathrm{~h}$ of culture. Pre-treatment of the cells with IFN- $\gamma(50 \mathrm{IU} / \mathrm{ml})$ resulted in a further increase of IL-8 secretion. In cells from healthy donors pretreated with IFN- $\gamma$, SEA at $1.0 \mu \mathrm{g} / \mathrm{ml}$ induced release of $1009 \mathrm{pg} / \mathrm{ml} \mathrm{IL-8} \mathrm{(733.0-1216} \mathrm{pg/ml,} \mathrm{median} \mathrm{(range))} \mathrm{while} \mathrm{in} \mathrm{cells} \mathrm{from} \mathrm{asthmatic}$ donors the same treatment induced significantly higher IL-8 secretion - I550 pg/ml (I I 68.0-2000.0 $\mathrm{pg} / \mathrm{ml} \mathrm{p}=0.04)$. Normal cells pre-treated with IFN- $\gamma$ and then cultured with SEB at $1.0 \mu \mathrm{g} / \mathrm{ml}$ released $904.6 \mathrm{pg} / \mathrm{ml} \mathrm{IL}-8(666.5-1169.0 \mathrm{pg} / \mathrm{ml})$. Cells from asthmatics treated in the same way produced significantly higher amounts of IL-8 - $1665.0 \mathrm{pg} / \mathrm{ml}(\mathrm{I} I 68.0-2000.0 \mathrm{pg} / \mathrm{ml}, \mathrm{p}=0.0 \mathrm{I})$. Blocking antibodies to MHC class II molecules added to cultures stimulated with SEA and SEB, reduced IL- 8 secretion by about $40 \%$ in IFN- $\gamma$ unstimulated cultures and $75 \%$ in IFN- $\gamma$ stimulated cultures. No secretion of TNF- $\alpha$, RANTES and eotaxin was noted.
\end{abstract}

Conclusion: Staphylococcal enterotoxins may have a role in the pathogenesis of asthma.

\section{Background}

Staphylococcus aureus (S. aureus) is a common human pathogen associated with various local and systemic infections, characterized by inflammation dominated by polymorphonuclear leukocytes. It produces a set of toxins including staphylococcal enterotoxins and toxic shock syndrome toxin-1 which cause food poisoning and toxic shock syndrome respectively in humans and other species. These toxins are intermediate molecular weight proteins (22-20 kD) that also act as superantigens (SAgs) due 
to their ability to bind to MHC class II molecules on antigen presenting cells and stimulate all T cells bearing particular $\mathrm{V} \beta$ s on their $\mathrm{T}$ cell receptors [1].

The epithelium acts as a physiological barrier to diffusion [2] and after physical or chemical damage has occurred, inhaled allergens, irritants and agonists can have detrimental effects on the underlying smooth muscle [3]. Traditionally, the epithelium was considered to be an inert barrier dividing the external environment and the inner tissue of the lung. However, it is now accepted that it constitutes the interface between the internal milieu and the external environment and plays a pivotal role in controlling many airway functions including barrier and secretory functions [4-6]. Airway hyper-responsiveness and epithelial cell damage are associated commonly with asthma.

In view of the ever increasing evidence for the effects of staphylococcal superantigens on immuno-modulatory and pro-inflammatory cells, it is likely that there is an association between staphylococcal infection and the pathogenesis of atopic diseases such as dermatitis, rhinitis and asthma $[7,8]$. Enterotoxins produced by $S$. aureus and their specific IgE antibodies are thought to be important in worsening atopic dermatitis [7].

Studies have shown greater $S$. aureus colonisation in the skin of patients with atopic eczema/dermatitis syndrome (AEDS) $(80-100 \%)$ than in the skin of normal healthy subjects (5-30\%). Indeed S. aureus constitutes up to $80 \%$ of the normal flora in atopic individuals and S. aureus isolated from the skin of at least $65 \%$ of AEDS patients secretes the Sags, S. aureus enterotoxin A (SEA), S. aureus enterotoxin B (SEB), S. aureus enterotoxin C (SEC), $S$. aureus enterotoxin D (SED) and Toxic Shock Syndrome Toxin-1 (TSST-1) [9].

In humans it is the nasal passage which is the most common site for $S$. aureus colonization [10]. Whereas more than $50 \%$ pathogenic isolates of $S$. aureus produce one or more SAgs exotoxins, even strains isolated from asymptomatic carriers can produce SAgs [11]. Given their anatomical localization and ability to produce exotoxins, it is likely that the nasal passage is exposed to bacterial SAgs [1].

In comparison to AEDS, few studies have documented the role of $S$. aureus or its SAgs in allergic or non-allergic airway disease. Earlier investigations suggested an allergy to certain bacteria as an important cause of exacerbation of the disease in patients suffering from allergic airway disease $[12,13]$. However, the tests used whole bacterial lysates, were highly unspecific and no correlations were found among these results.
Interferon-gamma (IFN- $\gamma$ ) is known to induce major histocompatibility complex class II expression on bronchial epithelial cells in vitro $[14,15]$. In vivo the expression of MHC class II molecules is enhanced in asthma and lung neoplastic disease, allowing bronchial epithelial cells to function as antigen presenting cells and to interact with $\mathrm{T}$ cells $[15,16]$. Although the major role of MHC class II is to present antigens to T cells, engagement of MHC class II by superantigens and other bacterial products has also consequences for the class II expressing cells including increased cytokine secretion and apoptosis [16-18].

Even though the MHC class II molecule appears to be the major receptor for the staphylococcal enterotoxins, it has been shown that antibodies to major histocompatibility complex I (MHC class I) can inhibit the binding of SEA and SEB to MHC class II negative macrophages [19]. Studies performed with MHC class II negative epithelial cell line demonstrated modulation of intracellular $\mathrm{Ca}^{2+}$ signal pathway in response to SEA [20]. These findings suggest that MHC class II molecule may not be the only receptor for staphylococcal exotoxins.

It has been recently demonstrated that interaction of live $S$. aureus with human tracheal epithelial cell line MM-39 stimulates release of IL-8, eotaxin and RANTES [21]. Our study investigates the effect of $S$. aureus products, SEA and SEB, on human nasal epithelial cells and tests the hypothesis that SEA and SEB can induce the release of proinflammatory cytokines from human nasal epithelial cells.

\section{Materials and methods}

Subjects were recruited from staff and students at Queen's University Belfast or the Belfast City Hospital. The study was approved by the Research Ethics Committee of Queen's University Belfast and all participants provided written informed consent. All subjects were non-smokers and were between 22-39 years old. They were in good general health and had no history of cardiac or renal disease.

Control subjects had no history of respiratory symptoms and some were atopic. Asthmatic subjects had a clinical history of physician-diagnosed asthma, with intermittent shortness of breath or wheeze within the previous 12 months. All subjects had an $\mathrm{FEV}_{1}$ of at least $60 \%$ predicted. They were not taking regular anti-inflammatory therapy and were maintained only on short-acting $\beta_{2}$ agonists. No subject had previously been prescribed a long acting $\beta_{2}$ agonist. They had not taken either inhaled or oral steroids in the six months preceding the commencement of the study. They had been free from upper respiratory tract infections for a minimum of four weeks preceding the commencement of the study. Atopy was defined by positive skin prick tests to 1 or more of 4 com- 
mon environmental allergens, including house dust mite (Dermatophagoides pterynonisinus (HDM), mixed grass pollen, cat and dog hair. Standardised allergen preparations (Dome-Hollister-Stier, Epernon Cedex, France) of house dust mite (Dermatophagoides pterynonisinus) (HDM), mixed grass pollen, cat and dog hair were applied to the volar aspect of the forearm, using a standard puncture technique as described by the European Academy of Allergology and Clinical Immunology [22]. Standardised solutions of histamine $(1 \% \mathrm{w} / \mathrm{v})$ and saline were used as positive and negative controls respectively. Atopy was defined as having one or more positive skin prick tests to test allergen solutions.

\section{Spirometry}

Spirometry was performed on all subjects. Spirometry was performed according to the American Thoracic Society Guidelines using a Vitalograph spirometer [23]. Prior to attending for spirometry, subjects were asked to withhold short acting $\beta_{2}$ acting agonists for at least eight hours. Records were taken of the subjects' height, weight and age. Predicted values for spirometry were then calculated from validated equations [24].

\section{Isolation of primary human nasal epithelial cells}

Nasal brushings were performed on all subjects using a standardized protocol and no local anaesthetics were used during the procedure. A bronchial cytology brush (TeleMed Systems Inc., MA, USA) was used to obtain two brushings from the external turbinate of each nostril. Each nostril was brushed once and the process was repeated providing the subject tolerated the process.

Cells were cultured in BEGM medium (Clonetics) until passage. Cells from passage 1 were frozen in liquid nitrogen and stored until used in experiments at passage 2-3. All the cells used in this work stained positive with pancytokeratine, cytokeratine $5+8$, cytokeratin 8 , cytokeratin 18 and negative with anti-vimentin and anti-cytokeratin 13 (not shown). Cells were grown in submersion cultures. For the experiments, human nasal epithelial cells (HNECs) were seeded into 24 well plates using a seeding density of $2 \times 10^{5}$ cells $/ \mathrm{ml}$ and a well volume of $300 \mu \mathrm{l}$. Cells were incubated at $37^{\circ} \mathrm{C}, 5 \% \mathrm{CO}_{2}$ for $6 \mathrm{~h}$. After the 6 $\mathrm{h}$ incubation period the cells were washed with PBS $\left(37^{\circ} \mathrm{C}, \mathrm{pH} 7.4\right)$ and fresh BEGM with or without $50 \mathrm{IU} / \mathrm{ml}$ IFN- $\gamma$ was added to the wells. Cells were left to incubate at $37^{\circ} \mathrm{C}$ for a further $24 \mathrm{~h}$. After $24 \mathrm{~h}$ (cells $80-90 \%$ confluent), media was removed and the cells were washed with PBS $\left(37^{\circ} \mathrm{C}, \mathrm{pH} 7.4\right)$ and fresh media added containing either SEA or SEB $(0.01$ and $1 \mu \mathrm{g} / \mathrm{ml})$ or nothing (control). Supernatants were collected 6 and 24 h post stimulation and stored at $-80^{\circ} \mathrm{C}$ until analysed by ELISA. In selected experiments before enterotoxin stimulation blocking anti-MHC class II antibody (IgG2a, clone L243,
BioLegend, San Diego, CA) was added at $50 \mu \mathrm{g} / \mathrm{ml}$ for 1 hour to cell cultures. After incubation enterotoxins were added as described above. The concentration of antibody used inhibited detection of MHC class II on human monocytic THP-1 cell line by 95\%. Purified mouse IgG2a (MOPC-173, BioLegend) was used as control.

\section{Spiking experiments}

Nasal epithelial cells were seeded into 24-well plates using a density of $2.5 \times 10^{5}$ cells $/ \mathrm{ml}$ and a well volume of 300 $\mu \mathrm{l}$. Cells were stimulated with either $1 \mu \mathrm{g} / \mathrm{ml}$ SEA or SEB. The supernatant was collected at $24 \mathrm{~h}$ of culture. Spiking was carried out by splitting the supernatant into two aliquots. The first aliquot was spiked with $500 \mathrm{pg} / \mathrm{ml}$ of either TNF- $\alpha$, RANTES or eotaxin. Cytokine concentrations were then measured by ELISA in both portions.

\section{Cell lysate experiments}

Once supernatants were collected, fresh BEGM (300 $\mu \mathrm{l})$ was added to each well. To lyse the cells the 24-well plate was freeze-thawed three times. The lysate was then centrifuged at $300 \mathrm{~g}$ for $5 \mathrm{~min}$ and subsequently aliquoted. Cytokine concentrations in lysates were measured by ELISA.

\section{ELISA assay}

Cytokine analyses were carried out using sandwich ELISA according to manufacturer's instructions (R \& D Systems).

\section{Reagents}

Recombinant IFN- $\gamma$ was purchased from PeproTech EC (London, UK). SEA and SEB were purchased from SigmaAldrich (Poole, UK). SEA and SEB were used in concentrations of 0.01 and $1 \mu \mathrm{g} / \mathrm{ml}$ which in preliminary experiments have been shown to be non-toxic for epithelial cells by MTT and trypan blue exclusion tests.

\section{Flow cytometric analysis}

Nasal epithelial cells were detached from culture dishes by means of nonenzymatic cell dissociation solution (Sigma) and were then stained with anti-HLA-DR, P, Q FITC conjugated monoclonal antibody (DAKO). MHC class II expression epithelial cells was assessed by flow cytometry (EPICS II; Coulter, Hialeah, Fl). Results were expressed as \% of positive cells and as mean fluorescence intensity.

\section{Statistical analysis}

Results are reported as median (range). Statistical comparisons were performed using Mann-Whitney U test, Friedman (Dunn's post-hoc test) and Wilcoxon matched pair test. All statistical analyses were carried out using SPSS (Version 11.5) for Windows and GraphPadPrism ${ }^{\circledR}$. GraphPadPrism $^{\circledast}$ was used to plot graphs. 


\section{Results}

\section{Subject characteristics}

A total of 20 subjects were included in the study (mean age $26.95 \pm 4.19 \mathrm{y}, 10$ female). Subject characteristics are summarised in table 1.

\section{Effect of Enterotoxin A (SEA) and Enterotoxin B (SEB) on primary human nasal epithelial cells}

Basal release of IL-8

There was no significant difference in the baseline release of IL- 8 from non-stimulated cells derived from normal (358.4 pg/ml, 304.2-509.6 pg/ml) and asthmatic subjects $(607.9 \mathrm{pg} / \mathrm{ml}, 424.9-717.4 \mathrm{pg} / \mathrm{ml}, \mathrm{p}=0.06)$ at $6 \mathrm{~h}$. However, in contrast cells derived from asthmatic subjects released significantly more IL- 8 at 24 h compared to those derived from control subjects (normal control $671.8 \mathrm{pg} /$ $\mathrm{ml}, 511.8-875.0 \mathrm{pg} / \mathrm{ml}$; asthmatic $1239.0 \mathrm{pg} / \mathrm{ml}, 859.9-$ $1547 \mathrm{pg} / \mathrm{ml}, \mathrm{p}=0.03$ ) (Figure 1).

\section{Effect of IFN- $\gamma$ on IL-8 release}

IFN- $\gamma$ pre-treatment $(50 \mathrm{U} / \mathrm{ml})$ of cells derived from normal subjects increased baseline IL- 8 release significantly at $6 \mathrm{~h}(370.4 \mathrm{pg} / \mathrm{ml}, 320.6-528.6 \mathrm{pg} / \mathrm{ml}, \mathrm{p}<0.01)$ and $24 \mathrm{~h}$ (694.4 pg/ml, 549.5-908.7 pg/ml, p < 0.01). Similarly, IL8 release from cells derived from asthmatic subjects was increased significantly at $6 \mathrm{~h}(657.7 \mathrm{pg} / \mathrm{ml}, 453.5-749.0$ $\mathrm{pg} / \mathrm{ml}, \mathrm{p}<0.01)$ and $24 \mathrm{~h}(1304.0 \mathrm{pg} / \mathrm{ml}, 919.6-1645.0$ $\mathrm{pg} / \mathrm{ml}, \mathrm{p}<0.01$ ) (Figure 1 ). Although there was no significant difference in the baseline release of IL- 8 after IFN- $\gamma$ pre-treatment between cells derived from normal and asthmatic subjects at $6 \mathrm{~h}(\mathrm{p}>0.05)$ the difference was significant at $24 \mathrm{~h}(\mathrm{p}=0.02)$.

\section{IL-8 release in response to SEA}

SEA caused significant IL-8 release from nasal epithelial cells derived from control and asthmatic subjects at both 6 and $24 \mathrm{~h}$ (both concentrations tested). The median values of IL-8 concentration were at $6 \mathrm{~h}$ incubation with 1.0 $\mu \mathrm{g} / \mathrm{ml} \mathrm{SEA} \mathrm{-} 387.0 \mathrm{pg} / \mathrm{ml}$, at $24 \mathrm{~h}$ incubation $848.8 \mathrm{pg} / \mathrm{ml}$ for $0.01 \mu \mathrm{g} / \mathrm{ml}$ SEA and $923.7 \mathrm{pg} / \mathrm{ml}$ for $1.0 \mu \mathrm{g} / \mathrm{ml} \mathrm{SEA}$. Cells derived from asthmatic subjects released significantly more IL- 8 than those from control subjects at both $6 \mathrm{~h}(\mathrm{p}=0.04)$ and $24 \mathrm{~h}(\mathrm{p}=0.02)$ (Figure 2 and 3$)$. The median value of IL- 8 release for 6 hour stimulation with $0.01 \mu \mathrm{g} / \mathrm{ml}$ SEA was $710.9 \mathrm{pg} / \mathrm{ml}$ : for 24 hour stimulation with $0.01 \mu \mathrm{g} / \mathrm{ml} \mathrm{SEA} \mathrm{-} 1035 \mathrm{pg} / \mathrm{ml}$ and with $1.0 \mu \mathrm{g} / \mathrm{ml}$ $1367 \mathrm{pg} / \mathrm{ml}$. Pretreatment of cells with IFN- $\gamma(50 \mathrm{U} / \mathrm{ml})$ followed by toxin stimulation resulted in increased IL- 8 release. In cells from healthy donors pretreated with IFN$\gamma$, SEA at $1.0 \mu \mathrm{g} / \mathrm{ml}$ induced release of $1009 \mathrm{pg} / \mathrm{ml} \mathrm{IL-8}$ (median value) while in cells from asthmatic donors the same treatment induced significantly higher IL- 8 secretion - $1550 \mathrm{pg} / \mathrm{ml}(\mathrm{p}=0.04)$. (Figure 4 and 5).

\section{IL-8 release in response to SEB}

The highest concentration of SEB tested $(1 \mu \mathrm{g} / \mathrm{ml})$ induced significant IL- 8 release from cells derived from normal and asthmatic subjects at both 6 and $24 \mathrm{~h}$. The median values of IL- 8 release were $400.8 \mathrm{pg} / \mathrm{ml}$ for 6 hour stimulation and $814.0 \mathrm{pg} / \mathrm{ml}$ for 24 hour stimulation. SEB ( $1 \mu \mathrm{g} / \mathrm{ml}$ ) induced significantly more IL- 8 release from

Table I: Subject Demographics

\begin{tabular}{|c|c|c|c|c|c|c|c|}
\hline Patient ID & Age (years) & Sex & Status & Atopy & FEV $_{\text {I (L) }}$ & FEV $\%$ pred & FVC (L) \\
\hline I & 34 & $M$ & Normal & NA & 4.5 & 110 & 6.2 \\
\hline 3 & 25 & $M$ & Normal & $A$ & 4.6 & 108 & 5.7 \\
\hline 4 & 27 & $M$ & Normal & NA & 4.0 & 92 & 5.3 \\
\hline 5 & 24 & $\mathrm{~F}$ & Normal & NA & 3.4 & 103 & 3.6 \\
\hline 6 & 25 & $M$ & Normal & NA & 5.2 & 122 & 6.35 \\
\hline 8 & 39 & $\mathrm{~F}$ & Normal & NA & 2.6 & 116 & 3.3 \\
\hline 9 & 25 & $\mathrm{~F}$ & Normal & $A$ & 3.6 & 100 & 4.0 \\
\hline 10 & 23 & $\mathrm{~F}$ & Normal & $A$ & 3.2 & 98 & 3.3 \\
\hline 14 & 27 & $M$ & Normal & NA & 5.2 & 111 & 6.4 \\
\hline 17 & 27 & $\mathrm{~F}$ & Normal & NA & 3.1 & 98 & 4.1 \\
\hline 2 & 32 & $M$ & Asthmatic & A & 4.9 & 121 & 4.7 \\
\hline 7 & 32 & $M$ & Asthma & $A$ & 4.5 & 82 & 6.4 \\
\hline 11 & 27 & $M$ & Asthmatic & A & 3.1 & 87 & 4.1 \\
\hline 12 & 25 & $\mathrm{~F}$ & Asthmatic & $A$ & 3.1 & 97 & 3.7 \\
\hline 13 & 24 & $\mathrm{~F}$ & Asthmatic & A & 3.4 & 114 & 3.8 \\
\hline 15 & 27 & $M$ & Asthmatic & NA & 3.9 & 95 & 5.4 \\
\hline 16 & 22 & $\mathrm{~F}$ & Asthmatic & A & 2.9 & 102 & 3.6 \\
\hline 18 & 25 & $M$ & Asthmatic & A & 3.3 & 79 & 4.7 \\
\hline 19 & 24 & $\mathrm{~F}$ & Asthmatic & $A$ & 2.9 & 94 & 3.4 \\
\hline 20 & 25 & $\mathrm{~F}$ & Asthmatic & A & 3.7 & 104 & 4.2 \\
\hline
\end{tabular}

$M=$ male, $F=$ female; $A$ = atopic, $N A=$ non-atopic; $F E V_{1}=$ forced expiratory volume in one second; FVC = forced vital capacity; $L=$ litres. 


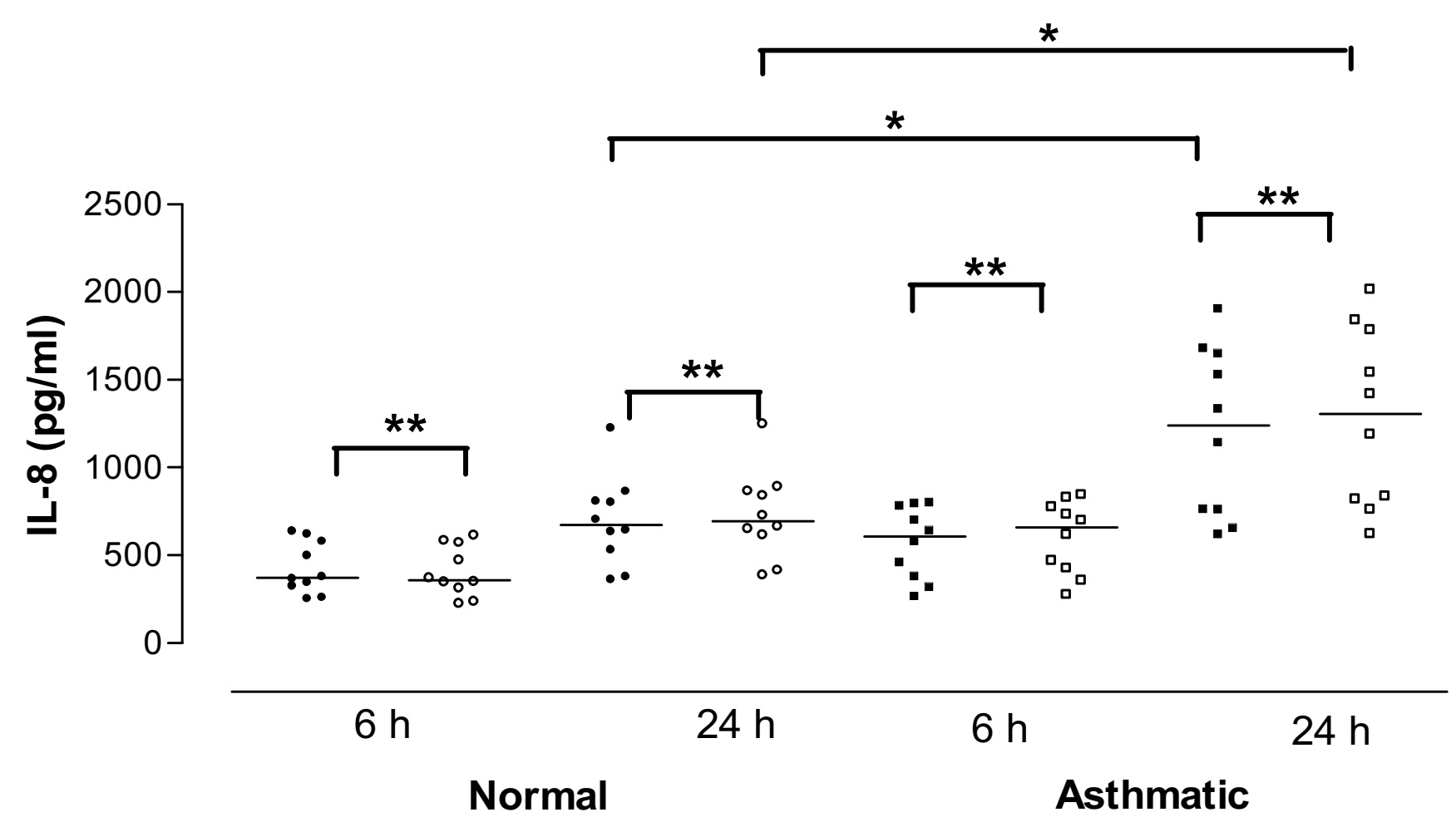

Figure I

Release of interleukin-8 (IL-8) in cell culture supernatants after interferon-gamma (IFN- $\gamma$ ) pretreatment. Data are shown as individual points, the line represents the median. Black symbols = no IFN- $\gamma$ pretreatment, open symbols $=$ IFN- $\gamma$ pretreatment. $\mathrm{P}$ values reaching statistical significance are marked on the graph. $*=\mathrm{P}<0.05 ; * *=\mathrm{P}<0.0 \mathrm{I}$.

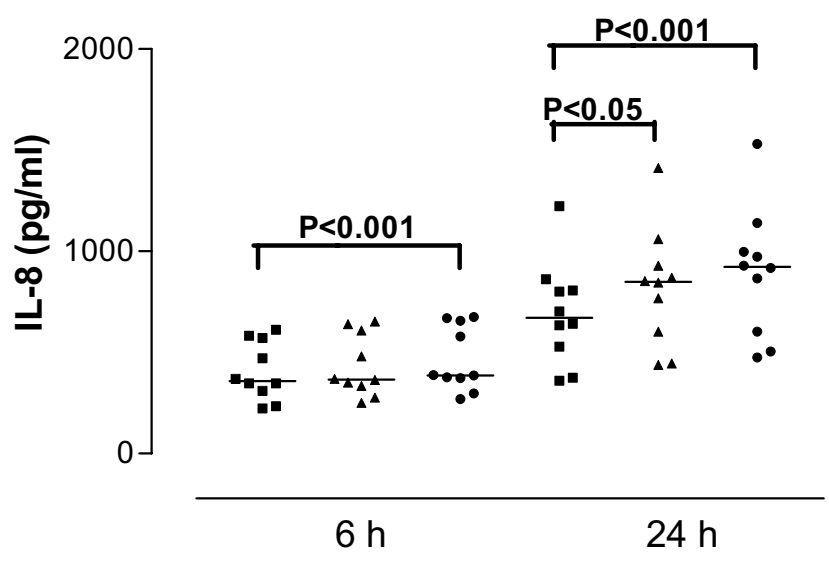

Figure 2

Interleukin-8 (IL-8) release from cells derived from normal subjects in response to SEA after 6 and 24 hour stimulation. Data are shown as individual points, the line represents the median. $\mathbf{\square}=$ control (unstimulated cells), $\boldsymbol{\Delta}=0.01 \mu \mathrm{g} / \mathrm{ml}$ SEA, $=1 \mu \mathrm{g} / \mathrm{ml}$ SEA. Median values of IL-8 release at 6 hours: control $P$ values reaching statistical significance are indicated on the graph.



Figure 3

Interleukin-8 (IL-8) from cells derived from asthmatic subjects in response to SEA after 6 and 24 hour stimulation. Data are shown as individual points, the line represents the median. $\boldsymbol{\square}=$ control (unstimulated cells), $\boldsymbol{\Delta}=0.0 \mathrm{I} \mu \mathrm{g} / \mathrm{ml}$ $\mathrm{SEA}, \quad=\mathrm{I} \mu \mathrm{g} / \mathrm{ml}$ SEA. $\mathrm{P}$ values reaching statistical significance are indicated on the graph. 


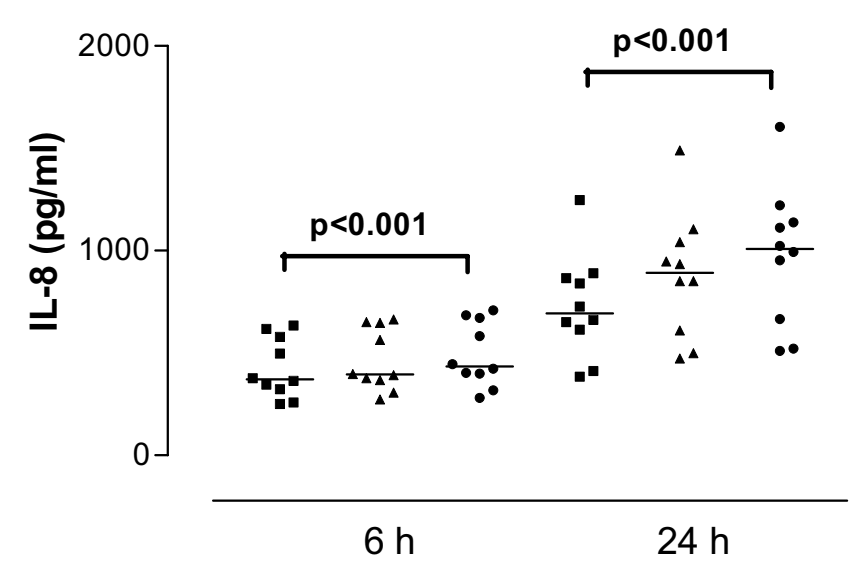

Figure 4

Interleukin-8 (IL-8) release from interferon-gamma (IFN- $\gamma$ )treated cells derived from normal subjects in response to SEA after 6 and 24 hour stimulation. Data are shown as individual points, the line represents the median. $\mathbf{\square}=$ control (unstimulated cells), $\boldsymbol{\Delta}=0.0 \mathrm{I} \mu \mathrm{g} / \mathrm{ml} \mathrm{SEA}, \boldsymbol{O}=\mathrm{I} \mu \mathrm{g} / \mathrm{ml}$ SEA. $\mathrm{P}$ values reaching statistical significance are indicated on the graph.

cells derived from asthmatic subjects compared to cells derived from normal subjects at 6 and $24 \mathrm{~h}(\mathrm{p}=0.02$ and 0.01 respectively) The median values of IL- 8 release from asthmatic cell cultures were $737.9 \mathrm{pg} / \mathrm{ml}$ for 6 hour and $1493.0 \mathrm{pg} / \mathrm{ml}$ for 24 hour stimulation (Figure 6 and 7). Pretreatment of cells with IFN- $\gamma$ followed by toxin stimu-

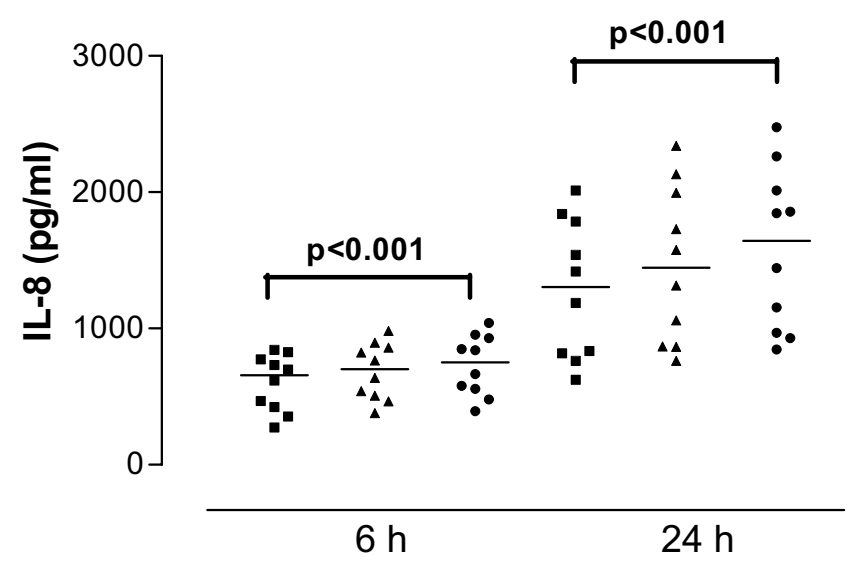

Figure 5

Interleukin-8 (IL-8) release from interferon-gamma (IFN- $\gamma$ )treated cells derived from asthmatic subjects in response to SEA after 6 and 24 hour stimulation. Data are shown as individual points, the line represents the median. $\mathbf{\square}=$ control (unstimulated cells), $\boldsymbol{\Delta}=0.0 \mathrm{l} \mu \mathrm{g} / \mathrm{ml} \mathrm{SEA}, \boldsymbol{O}=\mathrm{I} \mu \mathrm{g} / \mathrm{ml} \mathrm{SEA} . \mathrm{P}$ values reaching statistical significance are indicated on the graph.

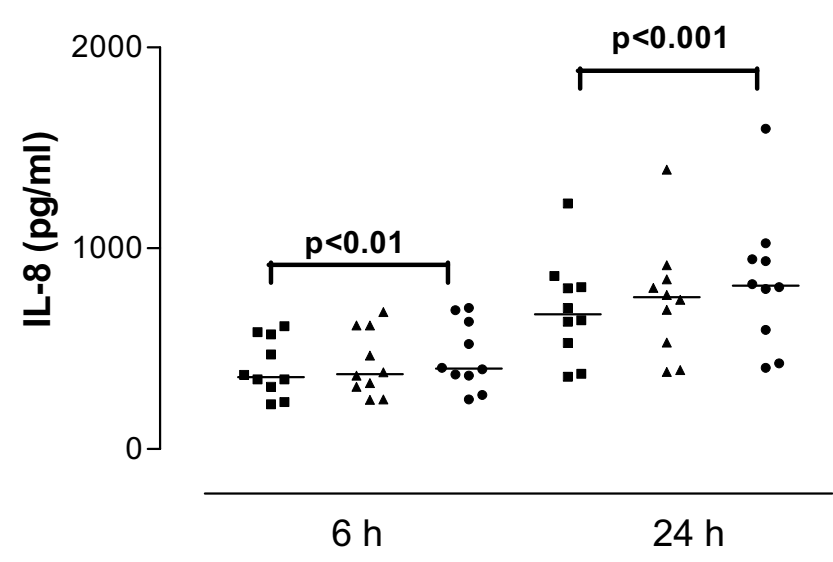

Figure 6

Interleukin-8 (IL-8) release from cells derived from normal subjects in response to SEB after 6 and 24 hour stimulation. Data are shown as individual points, the line represents the median. $\mathbf{\square}=$ control (unstimulated cells), $\boldsymbol{\Delta}=0.0 \mathrm{I} \mu \mathrm{g} / \mathrm{ml}$ $\mathrm{SEB}, O=\mathrm{I} \mu \mathrm{g} / \mathrm{ml}$ SEB. $\mathrm{P}$ values reaching statistical significance are indicated on the graph.

lation resulted in increased IL- 8 release. Normal cells pretreated with IFN- $\gamma$ and then cultured with SEB at $1.0 \mu \mathrm{g} /$ $\mathrm{ml}$ released $904.6 \mathrm{pg} / \mathrm{ml}$ IL-8 (median value). Cells from asthmatics treated in the same way produced significantly higher amounts of IL- $8-1665.0 \mathrm{pg} / \mathrm{ml}(\mathrm{p}=0.01)$ (Figure 8 and 9).

TNF- $\alpha$, RANTES and eotaxin release

Recent studies performed with S.aures added to airway epithelial cell culture have demonstrated robust response
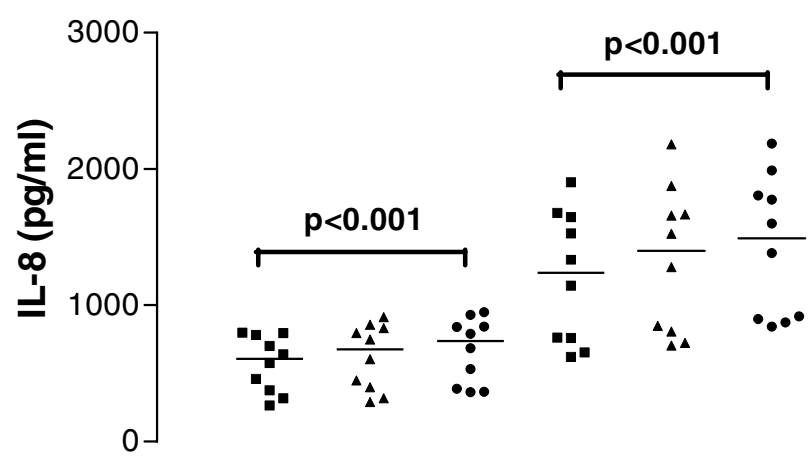

$6 \mathrm{~h}$

$24 \mathrm{~h}$

Figure 7

Interleukin-8 (IL-8) release from cells derived from asthmatic subjects in response to SEB after 6 and 24 hour stimulation. Data are shown as individual points, the line represents the median. $\mathbf{\square}=$ control (unstimulated cells), $\boldsymbol{\Delta}=0.0 \mathrm{l} \mu \mathrm{g} / \mathrm{ml}$ $\mathrm{SEB}, \quad=\mathrm{I} \mu \mathrm{g} / \mathrm{ml}$ SEB . $\mathrm{P}$ values reaching statistical significance are indicated on the graph. 


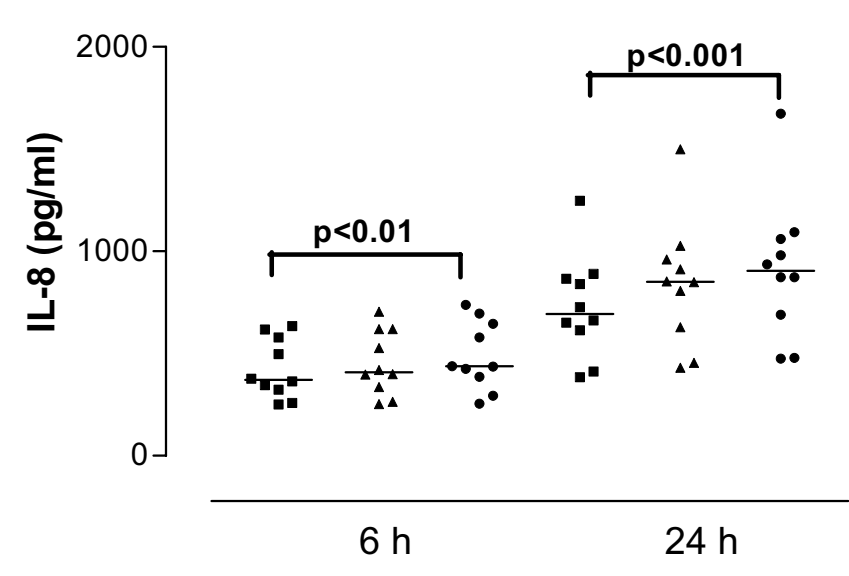

Figure 8

Interleukin-8 (IL-8) releases from interferon-gamma (IFN- $\gamma$ )treated cells derived from normal subjects in response to SEB after 6 and 24 hour stimulation. Data are shown as individual points, the line represents the median. $\mathbf{\square}=$ control (unstimulated cells), $\boldsymbol{\Delta}=0.0 \mathrm{I} \mu \mathrm{g} / \mathrm{ml} \mathrm{SEB}, \boldsymbol{O}=\mathrm{I} \mu \mathrm{g} / \mathrm{ml} \mathrm{SEB}$. $\mathrm{P}$ values reaching statistical significance are indicated on the graph.

by secretion of proinflammatory cytokines including RANTES and eotaxin [21]. In our experiments TNF- $\alpha$, RANTES and eotaxin were not detectable in cell culture supernatants collected at 6 and 24 h post stimulation with SEA or SEB. The detection limit for these assays was $2 \mathrm{pg} /$ ml (data not shown).

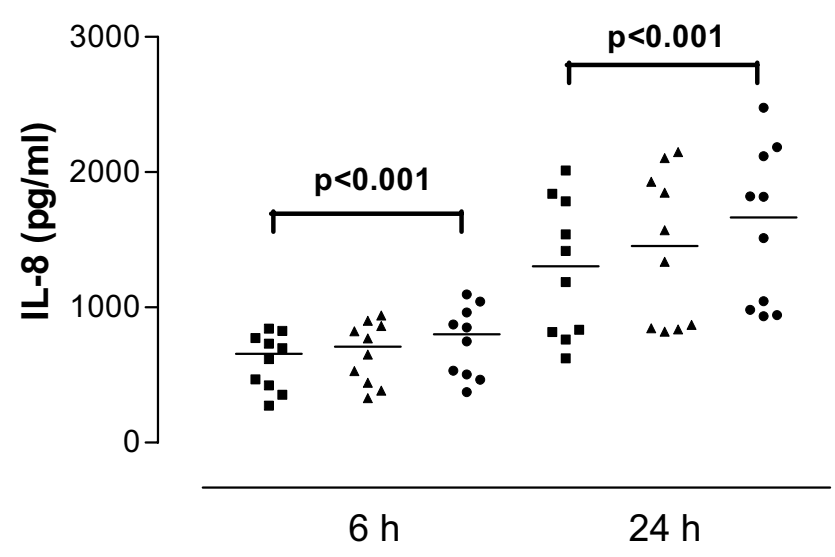

Figure 9

Interleukin-8 (IL-8) release from interferon-gamma (IFN- $\gamma$ )treated cells derived from asthmatic subjects in response to SEB after 6 and 24 hours stimulation. Data are shown as individual points, the line represents the median. $\mathbf{\square}=$ control (unstimulated cells), $\boldsymbol{\Delta}=0.0 \mathrm{I} \mu \mathrm{g} / \mathrm{ml} \mathrm{SEB}, \boldsymbol{O}=\mathrm{I} \mu \mathrm{g} / \mathrm{ml} \mathrm{SEB}$. $\mathrm{P}$ values reaching statistical significance are indicated on the graph.
Table 2: Flow cytometric analysis of HLA class II expression on nasal epithelial cells.

\begin{tabular}{lll}
\hline Human nasal epithelial cells & \% positive & Mean fluorescence \\
\hline Normal & $2.5 \pm 0.63$ & $205 \pm 40$ \\
Normal + IFN- $\gamma$ & $10.2 \pm 2.69$ & $1145 \pm 30 \mathrm{I}$ \\
Asthmatic & $2.03 \pm 0.47$ & $193 \pm 37$ \\
Asthmatic + IFN- $\gamma$ & $11.76 \pm 1.87$ & $1013 \pm 189$ \\
\hline
\end{tabular}

Nasal epithelial cells were detached from culture dishes by means of nonenzymatic cell dissociation solution and were then stained with anti-HLA-DR, P, Q, FITC-conjugated monoclonal antibody. Membrane fluorescence was analysed by flow cytometry.

\section{Spiking experiments}

In order to ascertain that inability to detect RANTES, TNF$\alpha$ and eotaxin was not due to fast degradation of cytokines in culture supernatant, spiking experiments were performed as described in Materials and Methods. Results obtained from these experiments showed that TNF- $\alpha$ was fully recoverable from all supernatants measured, whilst $90.8 \pm 7.6 \%$ of IL- $8,74 \pm 8.1 \%$ of RANTES and $86.5 \pm 7.7$ $\%$ of Eotaxin was recoverable as measured by ELISA.

\section{Cell associated cytokines}

In order to establish whether cytokines under study were stored intracellularly and failed to be secreted, we measured their concentration in cell lysates obtained from unstimulated cells and cells stimulated with enterotoxins. IL- 8 was present in cell lysates from stimulated cells and was not detected in lysates from unstimulated cultures. TNF- $\alpha$, RANTES and eotaxin were not detected in any of the patients' cell lysates (data not shown).

\section{HLA class II expression on nasal epithelial cells}

Flow cytometric analysis of class II molecules expression revealed that only a small proportion of cells both from normal and asthmatic subjects were class II positive (healthy $2.5 \% \pm 0.63$, mean fluorescence (mf) $205 \pm 40$, asthmatics $2.03 \% \pm 0.47, \mathrm{mf} 193.8 \pm 37.2)$. After stimulation with IFN- $\gamma$ there was a small increase in percentage of HLA class II positive cells (healthy $10.2 \% \pm 2.96$, mf 1145 \pm 301 ; asthmatics $11.76 \% \pm 1.87, \mathrm{mf} 1013 \pm 189)$. No significant difference between cells from normal and asthmatic subjects was observed both under basal and stimulated conditions $(\mathrm{p}<0.01)$. (Table 2$)$

Involvement of MHC class II molecules in stimulation of HNEC by SEA and SEB.

Normal HNEC $(n=5)$ were pretreated for $24 \mathrm{~h}$ with 50 IU of IFN- $\gamma / \mathrm{ml}$ (or left untreated for control HNEC) and then were incubated with SEA or SEB $(1 \mu \mathrm{g} / \mathrm{ml})$ in the presence or absence of anti-MHC class II blocking antibody $(50 \mu \mathrm{g} /$ $\mathrm{ml}$ ) as described in Material and Methods. Determination of IL-8 concentration in culture supernatants revealed that 
IL-8 secretion induced by SEA was inhibited by $40.5 \pm 3.2$ $\%$ in IFN- $\gamma$ unstimulated cultures and by $70.2 \pm 5.1 \%$ IFN- $\gamma$ treated cultures. For SEB stimulated cultures the obtained values showed $42.5 \pm 3.2 \%$ and $68.9 \pm 4.5 \%$. These results indicate at least partial involvement of $\mathrm{MHC}$ class II molecules in SEA and SEB induced secretion of IL8 from HNEC.

\section{Discussion}

The main finding of this study is that SEA and SEA in non toxic concentrations directly stimulate nasal epithelial cells to produce IL- 8 while they have no effect on TNF- $\alpha$, RANTES and eotaxin production. These four cytokines have pivotal roles in the inflammatory response in the lung. IL-8 and eotaxin act as chemoattractants for neutrophils [25-27] and eosinophils [28] while RANTES is a chemoattractant for many inflammatory cells including eosinophils [29] and T lymphocytes [30]. TNF- $\alpha$ is a multifunctional cytokine which is known not only to stimulate most cell types to release other cytokines including GM-CSF [31] but is also known to stimulate the production of cytotoxic oxygen metabolites from eosinophils [32].

Since increased concentrations of IFN- $\gamma$ are present in inflamed airways, the effect of preincubating cells with IFN- $\gamma(50 \mathrm{IU} / \mathrm{ml})$ prior to SAg stimulation was also investigated. IFN- $\gamma$ has many proinflammatory effects and has been shown to play an important role in early childhood asthma through the upregulation of ICAM-1 [33] and the cellular receptor for TNF- $\alpha$ [34]. Other studies have demonstrated increased IFN- $\gamma$ in BAL and blood from atopic asthmatics including acute severe asthmatics [35-37]. It is conceivable then that increased levels of IFN- $\gamma$ in asthmatic airways result in upregulation of $\mathrm{MHC}$ class II expression seen in asthmatic airway epithelium [38]. In this study, cells from both subject groups were incubated with IFN- $\gamma$ prior to toxin stimulation to investigate what effect if any there was on the release of IL-8.

Cells derived from normal subjects released IL-8 at 6 and $24 \mathrm{~h}$ in response to both SEA and SEB, with significantly increased responses in cells from asthmatic patients. Pretreatment of normal cells with IFN- $\gamma$ followed by toxin stimulation resulted in increased IL- 8 release. A similar trend was observed in IL- 8 release from cells derived from asthmatic donors. IFN- $\gamma$ pretreated cells derived from asthmatic subjects released increased levels of IL-8 in response to SEA $(0.01 \mu \mathrm{g} / \mathrm{ml})$ and SEB $(1 \mu \mathrm{g} / \mathrm{ml})$ at $6 \mathrm{~h}$ while at $24 \mathrm{~h}$ there was significant increase in IL-8 in response to both concentrations of SEA and to $1 \mu \mathrm{g} / \mathrm{ml}$ SEB.

The mechanism of how staphylococcal enterotoxins activate cells has been linked to their ability to crosslink the
MHC class II molecules. The presence of HLA-DR antigens was demonstrated on IFN- $\gamma$ treated airway epithelial cells but very little on unstimulated cells [39]. We also demonstrate that MHC class II antigen expression on HNEC can be upregulated by incubation with IFN- $\gamma$. The induced increase is however of moderate magnitude not exceeding $15 \%$ of cultured cells. No significant differences between normal and asthmatic HNEC were noted. Despite modest expression of MHC class II molecules on epithelial cell membrane, addition of blocking anti-HLA-DR antibody decreased IL- 8 secretion in cultures of HNEC (40\% reduction in unstimulated cells and $70.2 \%$ reduction in IFN- $\gamma$ stimulated cells). These results indicate that enterotoxin binding to $\mathrm{MHC}$ class II receptors is at least partially responsible for the observed increase in IL- 8 secretion.

Similar study using HNEC has recently been published showing that SEB induces proinflammatory cytokine secretion in vitro [40]. This study however did not investigate MHC class II expression and did not attempt to characterise the receptor responsible for SEB binding.

Some of the recent studies have shown that not all effects exerted by SAgs can be attributed to class II binding and crosslinking. Arad et al. showed that all superantigens have the ability to stimulate cross-immunity against each other through interaction of a dodecapeptide region of the molecules with a host cell receptor not involving MHC class II or T cell receptor [41]. Later Shupp and colleagues suggested that this receptor was important for superantigen transcytosis across mucosal surfaces [42] The staphylococcal enterotoxins which are members of the SAgs family have receptors on intestinal cells that lead to emesis and diarrhea associated with food poisoning; these biological effects are independent of superantigenicity $[43,44]$. While these results do not rule out direct effect of these toxins on intestinal epithelium they show that toxins can gain rapid access to the immune system. Further studies in this area using polarized nasal epithelial cells are clearly warranted. Finally, Paterson et al. showed that TSST-1 stimulates human vaginal epithelial cells to chemokine production via non MHC class II receptor [45]. It is therefore conceivable that interaction of SEA and SEB with nasal epithelial cells leading to IL-8 secretion described here can be mediated not only by MHC class II molecules but also by other yet undefined receptor and the effects described in this paper are due to enterotoxin binding to both $\mathrm{MHC}$ and non $\mathrm{MHC}$ receptors. It is also difficult to explain higher secretion of IL-8 from asthmatic HNEC in comparison to epithelial cells from normal cells since both groups expressed similar level of MHC class II molecules. We can only speculate that other, yet undefined receptor is responsible for this effect. This clearly requires further investigation. 
Specific IgE to $S$. aureus SAgs is present in nasal polyp tissue, and levels correlate with markers of eosinophil activation and recruitment [46]. SEB selectively stimulates the production of interleukin-5 (IL-5) in patients with atopic eczema/dermatitis syndrome (AEDS) or allergic asthmatics but not in asymptomatic atopic or non-atopic individuals [6]. Given the central role of IL-5 in eosinophilia this provides further evidence that SEB may at least, play some role in allergic diseases such as AEDS and asthma. Further evidence that SAgs may play an important role in allergic diseases such as dermatitis, rhinitis and asthma comes from studies which report the prevalence of serum IgE antibodies to $S$. aureus enterotoxins. Sensitisation to $S$. aureus enterotoxins seems to be a factor in increasing serum eosinophil cationic protein (ECP) which is thought to be a reliable marker of clinical severity of allergic diseases including asthma and rhinitis [47].

As part of this study cell culture supernatants collected 6 and $24 \mathrm{~h}$ post SAg stimulation were analysed for TNF- $\alpha$, RANTES and eotaxin. However, in all 20 subject samples these mediators were not detectable. In vivo administration of SEB to mice has been shown to trigger an inflammatory response characterised by mucosal and airway recruitment of lymphocytes, eosinophils and neutrophils together with elevated levels of IL-4 in BAL fluid [48]. The same study also demonstrated that SEB markedly enhances the frequency detection of TNF- $\alpha$ in BAL fluid [49]. However extrapolating results from animal studies and relating them to human studies must be done so with caution. It has been documented that murine cells are up to 1000 times less responsive to $S$. aureus enterotoxins than human cells [50].

Release of RANTES in response to SEB has been demonstrated in the human colonic T84 epithelial cell line [51]. In a model of human fibroblast-like synoviocytes, engagement of MHC class II molecules by SEA resulted in an increase in the mRNA level and protein synthesis of RANTES and IL-8 [52] while stimulation of human PBMCs to release RANTES in response to SEB has also been demonstrated [53].

In the human system of polarized bronchial epithelial cells a marked alteration in the transcriptional expression profile of epithelial cells in response to live S. aureus and soluble virulence factors was observed. These included pro-inflammatory cytokine release such as IL-1 $\beta$, IL-8, eotaxin and RANTES $[21,54]$. It is possible that a mixture of soluble virulence factors induces vigorous proiflammatory cytokine response as a result of synergistic action of many bacterial products including exotoxins. Further studies using polarised HNEC should clarify the issue.
In conclusion this study indicates that SEA and SEB can induce an inflammatory response in human nasal epithelial cells. The responses to SEA and SEB are higher in asthmatic subjects and can be further elevated by preincubaion with IFN- $\gamma$. This would suggest that bacterial toxins such as SEA and SEB may play a role in the pathogenesis of asthma possibly via the recruitment of neutrophils into the asthmatic airway.

\section{Competing interests}

The author(s) declare that they have no competing interests.

\section{Authors' contributions}

GJOB carried out the cell culture experiments, analysis of cell culture supernatants and lysates and wrote the manuscript. GS introduced techniques used in the present study and carried out experiments related to MHC class II. GR recruited patients and performed nasal brushings, JSE ME and GS were involved in the design, supervision and writing of the manuscript. All authors have participated in the study design and evaluation, and have read, contributed and approved the manuscript.

\section{Acknowledgements}

This work was funded by Northern Ireland HPSS R\&D Office

\section{References}

I. Bachert C, Gevaert P, van Cauverberge P: Staphylococcus aureus enterotoxins: a key in airway disease? Allergy 2002, 57:480-4387.

2. Churg A: The uptake of mineral particles by pulmonary epithelial cells. Am J Respir Crit Care Med 1996, I 54: I I 24-I | 40.

3. Sparrow MP, Omari TI, Mitchell HW: The epithelial barrier and airway responsiveness. Can J Physiol Pharmacol 1995, 73:180-190.

4. Knight D: Epithelium-fibroblast interactions in response to airway inflammation. Immunol Cell Biol 200I, 79: I60-I64.

5. Holgate ST: The inflammation-repair cycle in asthma: the pivotal role of the airway epithelium. Clin Exp Allergy 1998, 28(Suppl 5):97-I03.

6. Holgate ST, Davies DE, Lackie PM, Wilson SJ, Puddicombe SM, Lordan JL: Epithelial-mesenchymal interactions in the pathogenesis of asthma. J Allergy Clin Immunol 2000, 105: 193-204.

7. Heaton T, Mallon D, Venaille T, Holt P: Staphylococcal enterotoxin induced IL-5 stimulation as a cofactor in the pathogenesis of atopic disease: the hygiene hypothesis in reverse? Allergy 2003, 58:252-256.

8. Rossi RE, Monasterolo G: Prevalence of serum IgE antibodies to the Staphylococcus aureus enterotoxins (SAE, SEB, SEC, SED, TSST-I) in patients with persistent allergic rhinitis. Int Arch Allergy Immunol 2004, I 33:26I-266.

9. Breuer K, Kapp A, Werfel T: Bacterial infections and atopic dermatitis. Allergy 200I, 56:1034-I04I.

10. Chambers HF: The changing epidemiology of Staphylococcus aureus? Emerg Infedct Dis 2001, 7:178-182.

II. Becker K, Friedrich AW, Lubritz G, Weilert M, Peters G, von Eiff C Prevalence of genes encoding pyrogenic toxin superantigens and exfoliative toxins among strains of Staphylococcus aureus isolated from blood and nasal specimens. J Clin Microbiol 2003, 4l:|434-|439.

12. Bacigaluppi JE, Negroni R, de Severino HM: Bacterial allergy in allergic rhinitis and bronchial asthma. Ann Allergy 1979, 42:95-98.

13. Tee RD, Pepys J: Specific serum IgE antibodies to bacterial antigens in allergic lung disease. Clin Allergy 1982, 12:439-450. 
14. Salik E, Tyorkin M, Mohan S, George I, Becker K, Oei E, Kalb T, Sperber $\mathrm{K}$ : Antigen trafficking and accessory cell function in respiratory epithelial cells. Am J Respir Cell Mol Biol 1999, 21:365-379.

15. Saunders NA, Smith RJ, Jetten AM: Differential responsiveness of human bronchial epithelial cells, lung carcinoma cells and bronchial fibroblasts to interferon- $\gamma$ in vitro. Am J Respir Cell Mol Biol I994, I I: I47-I52

16. Rossi GA, Sacco O, Balbi B, Oddera T, Mattioni G, Corte C, Ravazzoni $C$, Allegra L: Human ciliated bronchial epithelial cells expression of the HLA-DR antigens and of the HLA-DR alpha gene, modulation of HLA-DR antigens by gammainterferon and antigen-presenting function in the mixed leukocyte reaction. Am J Respir Cell Mol Biol 1990, 3:43I-439.

17. Fan X, Gunasena H, Cheng Z, Espejo R, Crowe SE, Ernst PB, Reyes VE: Helicobacter pylori urease binds to class II MHC on gastric epithelial cells and induces their apoptosis. I Immunol 2000, 165:1918-1924.

18. Truman JP, Garban F, Choqueux C, Charron D, Mooney N: HLA class II signaling mediates cellular activation and programmed cell death. Exp Hematol 1996, 24:|409-14I5

19. Beharka AA, landolo IJ, Chapes SK: Staphylococcal enterotoxins bind H-2Db molecules on macrophages. Proc Natl Acad Sci USA 1995, 92:6294-6298.

20. Hu L-D, Suga S, Omoe K, abe $Y$, Shinigawa K, Wakui M, Nakane A: Staphylococcal enterotoxin A modulates intracellular Ca2+ signal pathway in human intestinal epithelial cells. FEBS Letters 2005, 579:4407-44I2.

21. Escotte S, AI Alam D, Le Naour R, Puchelle E, Guenounou M, Gangloff SC: $T$ cell chemotaxis and chemokine release after Staphylococcus aureus interaction with polarized airway epithelium. Am J Respir Cell Mol Biol 2006, 34:348-354.

22. European Academy of Allergology and Clinical Immunology: Skin tests used in type I allergy testing Position paper. Sub-Committee on Skin Tests of the European Academy of Allergology and Clinical Immunology. Allergy 1989, 44(SuppI I0): I-59.

23. American Thoracic Society: Standardization of spirometry 1987 update. Statement of the American Thoracic Society. Am Rev Respir Dis 1987, 136:1285-98.

24. Roca J, Burgos F, Sunyer J, Saez M, Chinn S, Anto JM, Rodriguez-Roisin $\mathrm{R}$, Quanjer PH, Nowak D, Burney P: References values for forced spirometry. Group of the European Community Respiratory Health Survey. Eur Respir J 1998, I I: I354-62.

25. Fahy JV, Kim KW, Liu J, Boushey HA: Prominent neutrophilic inflammation in sputum from subjects with asthma exacerbation. J Allergy Clin Immunol 1995, 95:843-852.

26. Teran LM, Campos MG, Begishvilli BT, Schroder JM, Djukanovic R, Shute JK, Church MK, Holgate ST, Davies DE: Identification of neutrophil chemotactic factors in bronchoalveolar lavage fluid of asthmatic patients. Clin Exp Allergy 1997, 27:396-405.

27. Teran LM, Johnston SL, Schroder JM, Church MK, Holgate ST: Role of nasal interleukin-8 in neutrophil recruitment and activation in children with virus-induced asthma. Am J Respir Crit Care Med 1997, 155:1362-1366.

28. Gleich GJ: Mechanisms of eosinophil-associated inflammation. J Allergy Clin Immunol 2000, I 05:65I-663.

29. Jose PJ, Griffiths-Johnson DA, Collins PD, Walsh DT, Moqbel R, Totty NF, Truong O, Hsuan JJ, Williams TJ: Eotaxin: a potent eosinophil chemoattractant cytokine detected in a guinea pig model of allergic airways inflammation. J Exp Med 1994, 179:88I-887.

30. Castro M, Bloch SR, Jenkerson MV, DeMartino S, Hamilos DL, Cochran RB, Zhang XE, Wang H, Bradley JP, Schechtman KB, Holtzman MJ: Asthma exacerbations after glucocorticoid withdrawal reflects $\mathbf{T}$ cell recruitment to the airway. Am J Respir Crit Care Med 2004, 169:842-849.

31. Munker R, Gasson J, Ogawa M, Koeffler HP: Recombinant human TNF induces production of granulocyte-monocyte colonystimulating factor. Nature 1986, 323:79-82.

32. Slungaard A, Vercellotti GM, Walker G, Nelson RD, Jacob HS: Tumor necrosis factor alpha/cachectin stimulates eosinophil oxidant production and toxicity towards human endothelium. J Exp Med 1990, I7 I:2025-2041.

33. Marguet C, Dean TP, Warner JO: Soluble intercellular adhesion molecule-I (sICAM-I) and interferon-gamma in bronchoalveolar lavage fluid from children with airway diseases. $\mathrm{Am} J$ Respir Crit Care Med 2000, 162:1016-1022.
34. Ruggiero V, Tavernier J, Fiers W, Baglioni C: Induction of the synthesis of tumor necrosis factor receptors by interferongamma. J Immunol 1986, I 36:2445-2450

35. Cembrzynska-Nowak M, Szklarz E, Inglot AD, Teodorczyk-Injeyan JA Elevated release of tumor necrosis factor-alpha and interferon-gamma by bronchoalveolar leukocytes from patients with bronchial asthma. Am Rev Respir Dis 1993, 147:29|-295.

36. ten Hacken NH, Oosterhoff Y, Kauffman HF, Guevarra L, Satoh T, Tollerud DJ, Postma DS: Elevated serum interferon-gamma in atopic asthma correlates with increased airways responsiveness and circadian peak expiratory flow variation. Eur Respir J 1998, II:312-316

37. Brown V, Warke TJ, Shields MD, Ennis M: T cell cytokine profiles in childhood asthma. Thorax 2003, 58:311-316

38. Nonaka M, Nonaka R, Jordana M, Dulovich J: GM-CSF, IL-8, IL-I R, TNF- $\alpha R$ and HLA-DR in nasal epithelial cells in allergic rhinitis. Am J Respir Cell Mol Biol I996, 3:1675-I68I.

39. Aubert V, Schneeberger D, Sauty A, Winter J, Sperisen P, Aubert J-D, Spertinin $F$ : Induction of tumour necrosis alpha and interleukin-8 gene expression in bronchial epithelial cells by toxic schock syndrome toxin I. Infect Immun 2000, 68: I20-I24.

40. Damm M, Quante G, Rosenbohm J, Rieckman R: Proinflammatory effects of Staphylococcus aureus exotoxin B on nasal epithelial cells. Otolaryngology-Head and Neck Surgery 2006, 134:245-249.

4I. Arad G, Levy R, Hillman D, Kaempfer R: Superantigen antagonist protects against lethal schock and defines a new domain for T cell activation. Nat Med 2000, 6:4|4-42I.

42. Shupp JW, Jet $\mathrm{M}$, Pontzer $\mathrm{CH}$ : Identification of a trancytosis epitope on staphylococcal enterotoxins. Infect Immun 2002, 70:2178-2186.

43. Harris TO, Grossman D, Kappler JW, Marrack P, Rich RR, Betley MJ: Lack of complete correlation between emetic and $T$ cell stimulatory activities of staphylococcal enterotoxins. Infect Immun 1993, 61:3175-3183.

44. Hamad AR, Marrack P, Kappler JW: Transcytosis of staphylococcal superantigen toxins. J Exp Med 1997, I85: | 447-I454.

45. Paterson ML, Ault K, Kremer MJ, Klengelhutz AJ, Davis CC, Squier $C A$, Schlievert PM: The innate immune system is activated by stimulation of vaginal epithelial cells with S. aureus and toxic shock syndrome toxin I. Infect Immun 2005, 73:2। 64-2I74.

46. Suh YJ, Yoon SH, Sampson AP, Kim HJ, Kim SH, Nahm DH, Suh CH, Park HS: Specific immunoglobulin E for staphylococcal enterotoxins in nasal polyps from patients with aspirin-intolerant asthma. Clin Exp Allergy 2004, 34:1270-1275.

47. Rossi RE Monasterolo G: Prevalence of serum IgE antibodies to the Staphylococcus aureus enterotoxins (SAE, SEB, SEC, SED, TSST-I) in patients with persistent allergic rhinitis. Int Arch Allergy Immunol 2004, I 33:26I-266.

48. Herz U, Ruckert R, Wollenhaupt K, Tschernig T, Neuhaus-Steinmetz $\mathrm{U}$, Pabst R, Renz H: Airway exposure to bacterial superantigen (SEB) induces lymphocyte-dependent airway inflammation associated with increased airway responsiveness - a model for non-allergic asthma. Eur J Immunol 1999, 29: 102I-I031.

49. Stiles BG, Bavari S, Krakauer T, Ulrich RG: Toxicity of staphylococcal enterotoxins potentiated by lipopolysaccharide: major histocompatibility complex class II molecule dependency and cytokine release. Infect Immun 1993, 61:5333-5338

50. Dionne S, Laberge S, Deslandres C, Seidman EG: Modulation of cytokine release from colonic explants by bacterial antigens in inflammatory bowel disease. Clin Exp Immunol 2003, 133:108-114.

5I. Jedrzkiewicz S, Kataeva G, Hogaboam CM, Kunkel SL, Strieter RM, McKay DM: Superantigen immune stimulation evokes epithelial monocyte chemoattractant protein I and RANTES production. Infect Immun 1999, 67:6I98-6I202.

52. Mehindate K, Thibodeau J, Dohlsten M, Kalland T, Sekaly RP, Mourad $\mathrm{W}$ : Cross-linking of major histocompatibility complex class II molecules by staphylococcal enterotoxin A superantigen is a requirement for inflammatory cytokine gene expression. Exp Med 1995, 182:1573-1577.

53. Cho YY, Astgen A, Hendel H, Issing W, Perrot JY, Schachter F, Rappaport J, Zagury JF: Homeostasis of chemokines, interferon production and lymphocyte subsets: implications for AIDS pathogenesis. Biomed Pharmacother 1997, 5 I:221-229.

54. Moreilhon C, Gras D, Hologne C, Bajolet O, Cottrez F, Magnone V Merten M, Groux H, Puchelle E, Barbry P: Live Staphylococcus 
aureus and bacterial soluble factors induce different transcriptional responses in human airway cells. Physiol Genomics 2004, 287:598-607.

Publish with Bio Med Central and every scientist can read your work free of charge

"BioMed Central will be the most significant development for disseminating the results of biomedical research in our lifetime. " Sir Paul Nurse, Cancer Research UK

Your research papers will be:

- available free of charge to the entire biomedical community

- peer reviewed and published immediately upon acceptance

- cited in PubMed and archived on PubMed Central

- yours - you keep the copyright

Submit your manuscript here:

http://www.biomedcentral.com/info/publishing_adv.asp
BioMedcentral 